\title{
Empowering Women and Ethnic Minority Groups to Collectively Market non Timber Forest Products from Community Forests in Cameroon
}

\author{
Marguerite Belobo Belibi ${ }^{1}$, Judith van Eijnatten ${ }^{1}$, William Armand Mala ${ }^{2}$ and Verina Ingram ${ }^{3,4}$ \\ 1. SNV Netherlands Development Organisation, PO Box 1239 Yaoundé, Cameroon \\ 2. BAD, African Development Bank, BP 323-1002 Tunis, Tunisia \\ 3. LEI, Wageningen UR, Postbus 29703, 2502 LS Den Haag, the Netherlands \\ 4. CIFOR Central Africa Regional Office, PO Box 2005, Nkolbisson, Yaoundé, Cameroon
}

\begin{abstract}
Community forestry (CF) was introduced in Cameroon in 1994 as a way to reduce poverty and enhance sustainable forest management. CF activities have primarily focused on timber exploitation rather than non-timber forest product (NTFP) collection, processing or marketing. The study reports on a two year participatory action research project that aimed to test ways of increasing access to income from NTFPs for women and people of the Baka ethnic group in nine CFs around Lomié, East Cameroon. After a participatory diagnosis of problems and stakeholders harvesting NTFPs, approaches to enhance processing, packaging, marketing, monitoring and data collection were evaluated. This led to the development of a market information system that aimed to balance supply and demandby providing information lines on market prices between buyers and sellers. Training support was provided for sustainable harvesting, and to aid harvesters to negotiate prices. This led to $100 \%$ price increase in group sales; an increase in selling prices by 39\% and an increased sales volume of six NTFPs: Irvingia gabonensis, Ricinodendron heudelotii, Pentacletra macrophylla, Baillonela toxisperma, Tetrapleura tetraptera, Pleurotus tuber-regiumresulting in a sales revenue increaseof 210\% (to €72,500) between 2010 and 2012. In a context where logging is restricted to men, supporting access to NTFP markets has led to increased income for women and Baka. These results suggest that support to sustainably harvest and market NTFPs can aid development and access to markets for women and minority ethnic groups. The implications for the revision of the law on small scale commercialization, and the ability of the CFs to continue this system without support from development NGOs are discussed.
\end{abstract}

Key words: Access to forest product markets, minorities, gender.

\section{Introduction}

People, forests and poverty have complex links in Central Africa.The many people who live within or adjacent to forests depend upon forest products to a high degree for subsistence and income, goods and services [1, 2]. Although 59\% of Cameroon is covered by forest, between 2000 and 2010, the annual net rate of deforestation was $0.03 \%$ and degradation $0.07 \%$ [3]. Deforestation and degradation are driven by expanding urban areas, subsistence and plantation

Corresponding author: Marguerite Belobo Belibi, research fields: Value chain development, community forestry resource and agriculture based livelihoods. E-mail: mbelobombia@snvworld.org; maguybelibi@yahoo.fr. agriculture and the building of new infrastructures [4, 5]. While these rates are relatively low compared to other tropical areas, the increasing population density of average 39 people per $\mathrm{km}^{2}$, combined with the fact that the $40 \%$ of the population live in poverty and $41 \%$ live in rural areas, places forest resources under pressure, with a high risk of the rate increasing if actions are not taken [6-8].

In Central Africa, Cameroon has been one of the pioneers in experimenting with forest reforms to respond to the challenges of development and conservation. Community forestry is one of the options under the Forest and Wildlife Law of 1994 (Articles 3 to 11 ) to respond to these challenges [9]. 

from Community Forests in Cameroon

The following elements extracted from the CF Manual of Procedures (CF Manual of Procedures 2008) indicate that a community forest (CF) is "a forest ofnon-permanentforest estate, subject to a management agreement between a village community and the forestry authority”. CFs aim tocreate jobs and generate income in rural areas; to improve the livelihoods and sustainable management ofthe environment while meeting the basic needs ofrural communities. A CF offers legal access for communities to forested areas of up to 5,000 hectares and enables them to plan and exploit forest resources, according to an approved management plan and timber inventory.The management of a CF is undertaken by a registered management entity, a "common initiative group", created by the representatives from the village communities in the target area, assisted by the local forestry administration.

In $80 \%$ of the 182 CFs granted up to 2011, the CF management entities focus on timber [10]. However, exploiting timber requires an inventory, a simple management plan, permits and equipment. Communities can rarely afford this investment. Combined with poor market access and skills profitable exploitation is rare [10]. In the face of these difficulties, some CFs joined forces to lower production costs and increase their negotiating power. An exemple is the «Regroupementdes Forêts Communautaires du Dja (REFOCOD)». This network was created in 2010 and clusters nine community forests covering nearly 35,000 ha in and around Lomié, in the East Region of Cameroon (Fig. 1) REFOCOD's mission is to defend its member's interests and support them in sustainable forest exploitation, with a focus on timber. Between 2010 and 2012 about 1,150 m of timber was sold by CFs in the network, generating $€ 47,000$. Some of the profits were invested in community projects. As between 13 to $25 \%$ of the annual allowable cut was actually exploited, the revenues generated were lower than foreseen.
Additionally, in and around the CFs there was illegallogging, placing pressure on the exploitable resources and on the operation of the CFs. Due to these factors, the economic viability of the $\mathrm{CF}$ and hence community satisfaction and investment in the CF was low.

Although the management plans of the CFs make reference to the harvest and collection of non-timber forest products (NTFPs) there are no planned activities in any of the CFs in the network or by REFOCOD to ensure the sustainability of this activity either for subsistence use or for sale. However, many of the NTFPs found in CFsare in high demandin West Africa, especially in Nigeria,as well as in other local, national and regional markets in Central Africa [12, 13]. In the Dja area, many NTFPs are consumed. The most common NTFPs for both consumption and sale are bushmeat, bush mango kernels (Irvingia gabonensis), ezezang/njangsang seeds (Ricinodendron heudelotii), mvout fruits of Trichoscypha acuminata, bitter kola bark (Garcinia kola), moabi seeds (sometimes processed into edible oil) (Baillonela toxisperma), fruits of Dacryodes macrophylla, the cola nuts (Cola verticillata), seeds of Coula edulis) andseeds of Tertrapleura tetraptera [14-16]. Generally, more people are involved in harvesting and selling NTFPs than in timber exploitation, and the people conducting these activities tend to be womenand the Baka minority group [17, 18]. Comparedto the requirements for CFs to harvest timber, NTFPs are more easily exploitedin volving less bureaucracy and costs [19, 20]. However, the current illegality of small scale NTFP commercialisation without the necessary permits has been heavily debated, during consultations from 2009 to date, to revise the 1994 Forest and Wildlife Law $[21,22]$.

\section{Description of the Intervention Area}

The area covered by the RECOFOD CFs is situated at $350 \mathrm{~km}$ from Yaoundé, the capital, in the dense 


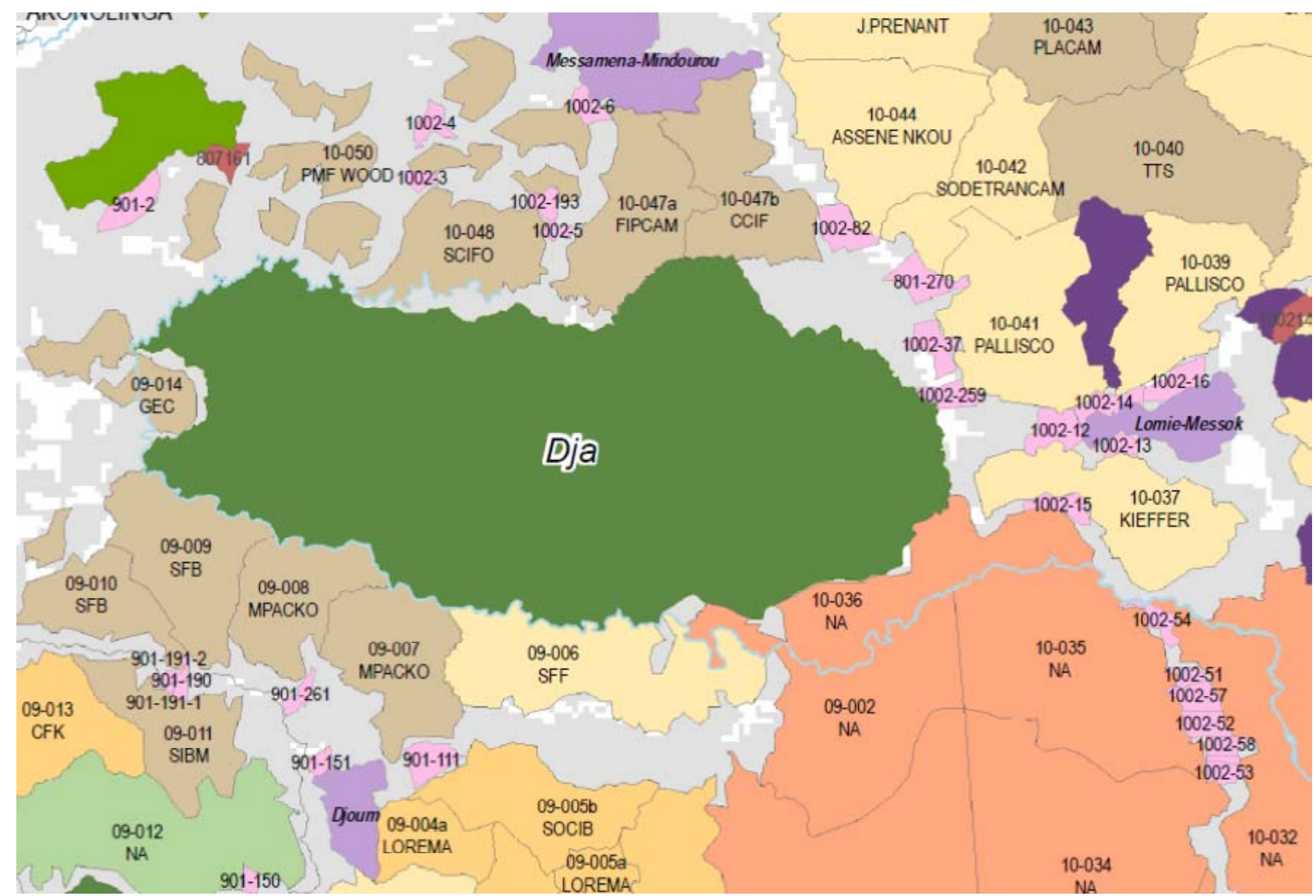

Fig. 1 Location of nine REFOCOD CFs (Dja area, East Region of Cameroon). Source adapted from World Resources Institute (WRI 2006).

lowland humid forest, a remote area with few paved roads. The CFs are adjacent to the Dja Forest Reserve, a protected area with a high level of plant and animal biodiversity, classified as UNESCO World Heritage Site in 1987 and adjacent to several logging concessions. Approximately 23,500 people live in the area of the Dja reserve [23]. The population comprises four main sedentary (Bantu) groups, namely Badjoue, Boulou, Fang and Nzime, representing 65\% of the total population, and two semi-nomadic indigenous groups, the Baka and Kaka representing approximately $35 \%$ of the population. The main activities carried out by the Bantu communities are farming and fishing, while the activities of the Baka focus on hunting and gathering.

\section{Methods}

As part of its program to strengthen the capacity of local organizations concerned with forest management, the Netherlands Development Organisation (SNV), an international not-for-profit development organisation, technically and financially supported the action plan of REFOCOD with the assistance of a local NGO 'Appui à l'Autopromotion de la Femme de la Bouma et Ngoko' (AAFEBEN) ${ }^{1}$, in partnership with the Belgian not-for-profit organisation 'NATURE ${ }^{+2}$. The aim was to sustainably commercialise NTFPs from the CFs and improve incomes through better entrepreneurship and the reinforcement of capacities using an appropriate institutional framework.

This paper documents the intervention process and

\footnotetext{
1 The Association for the Promotion of Women of the Boumba and Ngoko was responsible for women's development, NTFP processing and marketing.

${ }^{2}$ Nature+ supported the development of the market informationsystem as part of its "Projet de Development des Forets Communautaires (PDFC)”.
} 

from Community Forests in Cameroon

its impact, and discusses the findings and implications for social inclusion in forest management and sustainable development of forest based communities.

In 2010, SNV agreed and signed a contract for capacity building support to RECOFOD, with AAFEBENas local capacity builder. The approach to implement the action was based upon participatory action research (PAR); a form of experimental development-focused research that focuses on the effects of the researcher's direct actions of practice within a community with the goal of improving the performance and impact of the intervention. The RECOFOD CF members selected were judged to be the most organised forest management entities.

The first stage of a participatory diagnosis with members of REFOCOD was conducted in 2010. "Future scenarios" (a technique where participants indicated what situation they would like in the future) was used with the CF management entities to assess the current situation (thus providing a baseline) and develop scenarios for the future focusing on which forest resources to target. Constraints that would hinder the implementation of these scenarios were analysed, and action plans that could minimise these constraints were developed. The best scenario was selected based on the feasibility, the timeline and the potential impactfor community members. To implement the selectedscenario, the second stage involved capacity building of people in the REFOCOD CFs. After ascertaining interest, SNV facilitated 420 female harvesters to organise into 15 groups. Most of these groups were already established njangi ${ }^{3}$ women groups. These women groups were then formed into five clusters, each in contact with REFOCOD. Each group designated one person to be trained to train its members in NTFP quality, a secretary to recordthe amounts collected and sold by each group member and the group as a whole and to provide this information to REFOCOD, and a store

\footnotetext{
${ }^{3}$ Informal associations of individuals along neighbourhood, professional, age, gender or ethnic lines, often with a cultural and/or credit and saving function, also known as tontines.
}

keeper responsible for storing the NTFPs in a dedicated area. Prior to this intervention, an analysis of NTFP availability and their economic value in local, regional, and national markets was conducted as well as a review on collective action and forest-based associations to understand the main drivers of action, how and why groups operate, and how they can be used to improve performance in relation to the commercialisation of NTFPs.

In 2011, the marketing skills of the groups were developed. Lists of names, addresses and phone numbers of buyers, first in Lomié and then of wholesalers in Yaoundé, Ebolowa and Mbalmayo, were prepared and shared with the groups. The 15 groups were trained on sustainable NTFP harvesting, processing, storage, appropriate units of sale as determined by the market, market research, price negotiation and data management. Posters about the processes were developed and provided to the groups to reinforce the messages. The groups were supported to set up a group warehouse, and to use a recordkeeping system for the volume of NTFPs provided by each member. It was agreed that these products could not be removed nor sold by the member, but would be sold in bulk by the group. A guide on documentation and record keeping was provided to those designated to collect and consolidate NTFP data.

In 2012, during the NTFP collection season, the groups started community storage, negotiations with traders and group sales, which were recorded and monitored. Nature + facilitated the implementation of a market information system (MIS) with REFOCOD. Aworkshop was convened in Lomié with harvesters, buyers, CF management entities, community radio operatorsand local NGOs to exchange ideas on a MIS as a support for NTFP marketing.

Meanwhile REFOCOD was trained and coached by SNV for its role in data collection and consolidation. Data were collected from the members participating and the date, volume and price of NTFPs sold by each group was shared. Perceptions of the groups were 

from Community Forests in Cameroon

recorded about the success of the sales, difficulties in negotiating prices and communication, and how incomes were spent. The five clusters provided information on group sales to REFOCOD, which transmitted this information to the local community radio for broadcasting. At the end of the NTFP season, RECOFOD helped its members to include data collected in their annual reports, cross-checking the data and calculating summaries of the volumes sold, average prices, price increases and total revenues.

A participatory evaluation of the process and the factors influencing the collective actions and the efforts towards the establishment of small-forest enterprises was conducted by each of the 15 groups. The following variables were assessed: NTFP, effectiveness of communication, market access, nature of product, revolving funds, leadership in negotiation, tangible benefits for members, and organisational arrangements. Interviews onthe perceptions of change were solicited and filmed ${ }^{4}$ at the end of the support given to REFOCOD by SNV. The CF management entities conducted an evaluation on results, drawing lessons learnt and recommendations for the future.

\section{Results}

The participatory diagnosis conducted by REFOCOD with its members indicated that in 2010, NTFPs were mostly collected by women and Baka. NTFPs collection is considered as an appropriate activity for the poorest households. NTFPs were sold by individuals and not in groups. Many women were organized into traditional cultural and savings groups, known as njangihoweverthey were not used for collective marketing of NTFPs or other products. Harvesters had received no training in processing.

\footnotetext{
${ }^{4}$ Available on Treasures of the forest: Changes in the lives of women collectors https://www.youtube.com/watch?v=Kaf4Iu4ufhU, Treasures of the forest: Traditional production of moabi oil https://www.youtube.com/watch?v=d3w1kPUB-TQ , Treasures of the forest: Changes in the lives of traders https://www.youtube.com/watch?v=PqvwrFaUtGM, Treasures of the forest: Changes in the lives of community members https://www.youtube.com/watch?v=I1aE0Y6z0hw.
}

Most harvesters did not know the market values of NTFPs, although some women in Lomié had more information due to occasional exchanges with women of South and Central Cameroon.

The diagnosis showed that strengthening individual and group marketing was a priority for the following NTFPs: bush mango kernels, njangsang seeds, moabiseeds and oil, Tetrapleura teraptera seeds, 'ebaye' seeds (Pentacletra macrophylla) and 'koutou' mushrooms (Pleurotus tuber-regium). Participants indicated the following constraints:

- Lack of start capital to establish a revolving fund and purchase processing equipment and tools;

- Lack of knowledge on sustainable harvesting and processing techniques;

- Neglect by CF management entities of NTFPs as a source of income;

- Knowledge on storage and warehousing of NTFPs;

The impacts of the interventions on the processes and governance on NTFPs managementcompared to the baseline are summarised in Table 1, and were:

- Improved quality of NTFPs offered for sale

At the start of the project, bush mango kernels were of low grade quality, being black and smoky due to being traditionally processed (dried on a grid above a fire and stored on the household kitchen floor). Njangsang fruit was fermented for two weeks resulting in black hulls and dark seeds. The training and awareness of market standards resulted in bush mango being more quickly sun-dried and stored in dedicated, smoke-free and dry storage places. The resulting bush mango kernels were dry, clear and odourless and of a much higher quality. Similar results were obtained for Njangsang seeds. Quality increases reduce perishability (and therefore losses) and increases the product selling price.

- Upscaling stock

The new system of group sales and stocks allowed significant increase in product bulking. This made sales from the village more attractive to traders and wholesalers. 
Table 1 Changes in NTFP commercialisation by REFOCOD CF members between 2010and 2013.

\begin{tabular}{|c|c|c|}
\hline Parameter & Baseline as of March 2010 & Situation as of March 2013 \\
\hline \multicolumn{3}{|c|}{ Attention given to NTFPs by CFs } \\
\hline $\begin{array}{l}\text { Interest in NTFPs by CF } \\
\text { management entities }\end{array}$ & NTFPsnot a priority;focus was ontimber & $\begin{array}{l}\text { Interest of CF management entity in supporting } \\
\text { NTFP harvesting }\end{array}$ \\
\hline $\begin{array}{l}\text { Involvementof CF } \\
\text { community members in } \\
\text { NTFP activities }\end{array}$ & Traditionally a women and Baka activity & $\begin{array}{l}\text { Women, Baka and men are now involvedin NTFP } \\
\text { harvest and sales }\end{array}$ \\
\hline \multicolumn{3}{|l|}{ Collective action } \\
\hline Harvesting & By individual or family and friend groups & Collecting and storing in groups within the CF \\
\hline Data collection & Nodatacollected or analysed & $\begin{array}{l}\text { Data recorded by groups, synthesizedat group level } \\
\text { and gradually transferred by REFOCOD }\end{array}$ \\
\hline Sales & Individual & Individual and sales in groups within the CF \\
\hline \multicolumn{3}{|l|}{ Training } \\
\hline Processing & Traditional bush mango and Njansang processing & Improved bush mango and Njansang processing \\
\hline Product quality & Poor quality & Mainly good quality \\
\hline Product quantity & $\begin{array}{l}\text { Small quantities sold by individualsfor irregular } \\
\text { opportunistic sales }\end{array}$ & $\begin{array}{l}\text { Larger amountscollected and stored and amounts } \\
\text { known }\end{array}$ \\
\hline \multicolumn{3}{|l|}{ Commercialisation } \\
\hline Price & $\begin{array}{l}\text { Pricesfixed bybuyers, no or little information by } \\
\text { harvesters on prevailing market prices in local or } \\
\text { largeurban markets }\end{array}$ & $\begin{array}{l}\text { Average overall selling price increase of } 35 \% \text {, prices } \\
\text { negotiated and more frequently fixed by sellers, price } \\
\text { range in local and large urban markets known }\end{array}$ \\
\hline NTFP sales techniques & $\begin{array}{l}\text { Individual harvester sales, small quantities, sales to } \\
\text { small scale traders (middlemen) }\end{array}$ & $\begin{array}{l}\text { Group sales, sales to highest bidder, sales to small } \\
\text { scale traders and wholesalers, transparency in sales }\end{array}$ \\
\hline $\begin{array}{l}\text { Role of NTFP sales in } \\
\text { the CF }\end{array}$ & None & NTFP group sales included in CF annual reports \\
\hline
\end{tabular}

- Improved market access

The exchange of information on supply and demand through local community radio helped the groups adjust supply and increase it from previous years, tailoring the NTFPs harvested and the quality of processed products to requirements of traders.

\section{- CF awareness of NTFPs}

The CFs management entity and network have recognised that the collective exploitation of NTFPs is complementary to timber, is legal when enshrined in the CF management plan, and provides higher revenues for individual community members than timber exploitation. It is also seen as a less destructive activity than timber exploitation.

- Awareness of sustainability of forest management-livelihoods

Communities and harvesters came to perceive NTFP collection as more sustainable than timber. NTFP-bearing species are naturally regenerated and deliberately left and encouraged in farm fallows in the CFs. Training on sustainable harvesting was reported to have made harvesters aware of the impacts of the harvesting techniques used. The non-destructive techniques are perceived as sustainable, illustrated by a quote from a harvester in one of the evaluation meetings: "By exploiting NTFPs, we can improve forest conservation because NTFPs don't require cutting down trees, with NTFPs we don't waste the forest”.

The baseline situation and changes observed in 2013 are summarised in Table 1 below.

Results in NTFP market price and sales are listed below:

- Increased price

The combination of better quality products, large stocks, contacts with multiple buyers and adaptation to market demand, meant that the groups gained greater bargaining power than individual sellers. The selling price of a kilo of Njansang rose by 1,500 CFA (3.30 Euro) from 2010 and 2011 to on average 3,800 CFA (5.79 Euro), an increase of $39 \%$.

- Increased sales revenues

Revenues, shown in table 2, increased to a total of 


\section{from Community Forests in Cameroon}

4,755,300 CFA (around 72,600 Euro), an increase of 210\%between 2011 and 2012. Whilst a profitability analysis was not conducted, costs were not perceived as significantly different, as the changed processing and storage methods did not incur more time or costs.

- Balancing supply and demand

By bulking products and informing traders in person and through the radio, the market dynamics changed making the CF groups more attractive for larger scale traders and wholesalers to buy better quality products from the villages, saving time and transport costs.

These changes are summarized in table 2 .

In addition to the foregoing results the groups reported increased satisfaction and social cohesion from using the existing njangi groups to generate NTFP income. This also demonstrated the potential and importance of women's role in the $\mathrm{CF}^{5}$ [24].

\section{Analysis}

Analysis of the information collected by REFOCOD showed that the proceeds of improved processing and sales of NTFPs were used mainly to meet basic needs including children's schooling, family health and improving housing. This is illustrated by a quote from one of the harvesters during the evaluation: "In the past, we collected NTFPs; we stocked them in our homes. But we had no buyers, we earned nothing. Even if a buyer arrived, and he gave us five hundred, or one hundred francs, we could do nothing with that money. But now with the support of NGOs, of REFOCOD, of SNV.... really the women of Kongo are so happy with the money from NTFPs. We can achieve anything! We are able to send our children to school, we build and furnish our homes and we decorate them". Women indicated that NTFP revenues decreasedtheir dependence from thesole cash income earned by their

\footnotetext{
${ }^{5}$ Treasures of the Forest: Changes in the lives of community members https://www.youtube.com/watch?v=I1aE0Y6z0hw, Changes in the lives of womenhttps://www.youtube.com/watch?v=Kaf4Iu4ufhU.
}

husbands; they are proud to contribute financially to the needs of their families. Feed-back in 2014 indicated that groups continue collecting, processing and selling together at a good price.

\section{Discussion}

The positive impacts of training and introducing collective storage, sales and the MIS on buyer selling prices and revenues confirm previous experiences in Cameroon and internationally in other major forest areas that these activities can result in higher incomes for both parties [25-28]. This study indicates that incomes and profit increased for individual harvesters, as the costs of setting up the collective system were largely borne by SNV, and the ongoing costs of processing to produce higher quality products and group storage and sales are not significantly higher than traditional methods. However, the costs of maintaining this system are not clear. No institutional mechanisms to ensure that the costs for RECOFOD's role in collecting, summarizing and disseminating the market information were put in place by the end of the experiment.Traders also indicated their satisfaction with the system; they benefited from reduced transport and logistic costs and obtained better quality products.

Whilst the perceptions of communities and harvesters are that increased harvesting is viable and sustainable, the timescale of the study does not allow this to be confirmed. Although all the species involve nuts and seeds, which generally are not at risk due to destructive harvesting practices, it also includes products from species such as Baillionella toxpisperma which are threatened due to their multiple use value for both NTFP and timber, and which are now present in the area in very low densities [14, 20].

The gains in quality which have been made for Njansang and bush mango, suggest that developing quality standards and enhancing primary processing could also provide benefits to all those in the value chain from harvester to consumer. This reflects similar 
Table 2 NTFP sales and revenues per community forest group in 2012.

\begin{tabular}{|c|c|c|c|c|c|}
\hline Community Forest & \begin{tabular}{|l|} 
NTFP \\
collection \\
group \\
\end{tabular} & NTFP & $\begin{array}{l}\text { Quantity } \\
\text { collected } \\
(\mathrm{kg}) \\
\end{array}$ & $\begin{array}{l}\text { Quantity } \\
\text { sold } \\
(\mathrm{kg}) \\
\end{array}$ & Revenue $(€)$ \\
\hline \multirow{3}{*}{ AVILSO } & \multirow{3}{*}{ Leme-Pkwel } & Bush mango & 4,722 & 3,930 & 4,973 \\
\hline & & Njansang & 2,960 & 2,528 & 2,181 \\
\hline & & Moabi & 1,506 & 1,333 & 4,101 \\
\hline \multicolumn{5}{|l|}{ Sub-total } & 11,255 \\
\hline \multirow{2}{*}{$\begin{array}{l}\text { COBAKA, } \\
\text { COBAKAM, } \\
\text { LABISSAMA } \\
\text { COVINKO } 1\end{array}$} & \multirow[b]{2}{*}{ Lemengouar } & Bush mango & 7,310 & 6,578 & 11,310 \\
\hline & & Njansang & 392 & 392 & 356 \\
\hline \multicolumn{5}{|l|}{\begin{tabular}{|l} 
Sub-total \\
\end{tabular}} & 11,666 \\
\hline \multirow{3}{*}{$\begin{array}{l}\text { COBANKO ZIENGA } \\
\text { MINLEME }\end{array}$} & \multirow{3}{*}{ Mpolabor } & Bush mango & 30,404 & 25,706 & 45,170 \\
\hline & & Njansang & 288 & 288 & 443 \\
\hline & & Moabi & 3,012 & 2,666 & 4,101 \\
\hline \multicolumn{5}{|l|}{ Sub-total } & 49,714 \\
\hline \multicolumn{3}{|l|}{ Total } & 50,594 & 35,630 & 72,635 \\
\hline
\end{tabular}

Source: REFOCOD NTFP register 2012.

work on adding value through transformation and processing which can be an important factor enabling the inclusion of disadvantaged social groups in value chains, given a supportive institutional framework $[29,30]$.

\section{Conclusions}

The impacts of the intervention suggest that there are some implications for the main stakeholders to further enhance social inclusion in forest management and NTFP harvest and commercialization activities. These lessons apply to the women's groups and community forests, which can be seen as entrepreneurs and small businesses, the Ministry of Forestry and Wildlife, as the main government agency responsible for forest policy, and for development organizations, service providers and consultants.

The combination of capacity building, organisational and institutional strengthening and financial assistance are important prerequisites to enable experiments in forest management and commercialization of forest products to be adapted to the local context. Participatory action research can be a useful tool for development activities that provides feedback and allows self-reflection and adjustment of activities by all partners involved. Whilst this case shows that NTFPs can be important sources of revenue for social groups normally not included in forest management initiatives, it also suggests that as value of such products increases, there is a risk that this activity may be captured by dominant groups who will exploit vulnerable ones. This is particularly as timber exploitation generates lower revenues and benefits for a smaller number of people. The network, individual community forests and NGOs and government need to monitor this possibility and if warning signals occur, provide support for vulnerable groups to ensure that they retain access to these resources and markets. It is also important to ensure that these enterprises continue to grow sustainably and legally. The outcome of the soon-expected revision of the 1994 Forestry law for commercialisation at group and CF level may have significant implications.

The experiences also suggest that increased commercialization of these NTFPs requires monitoring of the impact on species and the forest ecosystem, to ensure that the level of extraction really is sustainable. For some of the mushroom NTFPs, very little is known about their ecology and sustainable levels of harvesting, indicating a gap in 


\section{from Community Forests in Cameroon}

knowledge. Possible ways of ensuring continued economic benefits are to explore domestication and cultivation.

The experience described in this paper shows a paradigm shift in the focus of forest governance that combines timber and non-timber products, and takes a wider perspective of the benefits that collective forest management and commercialisation can bring to benefit more individuals and social groups in forest based communities, as well as others in the value chain. A next step will be to ensure that these social groups become and remain included in decision making in the CF management institutions and networks.

\section{References}

[1] de Wasseige, C., Devers, D., Marcken, P., Eba'a, R. A., Nasi, R., and Mayaux, P. Eds. 2009. The Forests of the Congo Basin. State of the Forest 2008. Yaoundé, Cameroon, Office des publications de l'Union Européenne.

[2] FAO 2009. State of the World's Forests 2009. Rome, Food and Agricultural Organisation of the United Nations.

[3] de Wasseige, C., de Marcken, P., Bayol, N., Hiol, F., Mayaux, P., Desclée, B., Nasi, R., Billand, A., Defourny, P., and Eba'a, R. Eds. 2012. Les Forêts du Bassin du Congo-Etat des Forêts 2010. Luxembourg, Office des Publications de l’Union Européenne.

[4] DeFries, R. S., Rudel, T., Uriarte, M. and Hansen, M. 2010. "Deforestation Driven by Urban Population Growth and Agricultural Trade in the Twenty-first Century.” Nature Geoscience 3 (3): 178-81.

[5] Robiglio, V., Ngendakumana, S., Gockowski, J., Yemefack, M., Tchienkoua, M., Mbile, P., Tchawa, P., Tchoundjeu, Z., and Bolognesi, M. 2010. Reducing emissions from all land uses in Cameroon. Yaounde, ASB Partnership for the Tropical Forest Margins.

[6] Government of Cameroon 2010. 3rd Population and Housing Census 2005, Government of Cameroon.

[7] UNDP 2009. Human Development Report 2009 Overcoming barriers: Human mobility and development. UNDP. New York, UN.

[8] Ministry of Planning Programming and Regional Development 2007. Poverty Reduction Strategy Paper Progress Report January-December 2006. C. DRRP, Republic of Cameroon.

[9] République du Cameroun 1994. LOI N 94/01 portant régime des forêts, de la faune et de la pêche.

[10] Cuny, P. 2011. Etat des lieux de la foresterie communautaire et communale au Cameroun. Yaounde, Tropenbos International-Congo Basin.

[11] WRI, G. 2006. Situation de l'expolitation forestiere au Cameroun, Global Forest Watch and WRI, Washington, DC, USA.

[12] Ingram, V., and Schure, J. 2010. Review of Non Timber Forest Products (NTFPs) in Central Africa: Cameroon. Atelier Sous-Regional sur«l'Harmonisation des Revues Nationales sur les Produits Forestiers Non Ligneux (PFNL) en Afrique Centrale. FORENET. Yaounde, CIFOR: $166+\mathrm{v}$.

[13] SNV, Ngouwou, Y., Fon, J. N., Boum, R. M., Ngeuko, R., and Koukam, R. 2010. Etude de marche des produits forestieres non ligneux (PFNL) au Cameroun et dans les pays voisins. Yaounde, FAO-CIFOR-SNV-World Agroforestry Center-COMIFAC.

[14] Vermeulen, C., and Doucet J.-L. 2004. Conservation and Sustainable Use of Non-Timber Forest Products in Favour of Local Communities within Integrated Forest Management in Central Africa. International Symposium Tropical Forests in a Changing Global Context, Brussels, Royal Academy of Overseas Sciences.

[15] Samndong, R. A. 2009. Forestry Law Reforms, Commercial Logging Activities and their Impacts on Rural Livelihoods in the Rainforest of Cameroon. Master of Science (Development Studies Master, Norwegian University of Life Sciences).

[16] van der Goes, A., and Ngueko, R. 2009. Market Information System as a contribution for social inclusion in NTFP value chain. XIII Congrès forestier mondial, Buenos Aires, Argentina, FAO.

[17] Tobith, C., and Cuny, P. 2006. "Genre et Foresterie Communautaire au Cameroun. Quelles Perspectives Pour Les Femmes?” Bois et ForÊts des Tropiques 289 (3): $17-26$.

[18] Ingram, V., Schure, J., Tieguhong, J. C., Ndoye, O., Awono, A., and Iponga, D. M. 2014. "Gender Implications of Forest Product Value Chains in the Congo Basin.” Forests, Trees and Livelihoods 23. Special Edition Forest and tree value chains (1-2).

[19] MINFOF 2009. Manuel des procédures d'attribution et normes de gestion des forêts communautaires. Yaoundé, Cameroun, Ministère de l'Environnement et des Forêts.

[20] Ingram, V. 2014. Win-wins in forest product value chains? How governance impacts the sustainability of livelihoods based on non-timber forest products from Cameroon. Ph.D, University of Amsterdam.

[21] FAO 2010. Contributions to the revision of Law $n^{\circ}$ 94-01 of 20th January 1994 to lay down Forestry, Wildlife and Fisheries Regulations in Cameroon and its texts of 

from Community Forests in Cameroon

application. Project GCP/RAF/408/EC «Mobilisation et Renforcement des Capacités des Petites et Moyennes Entreprises impliquées dans les Filières des Produits Forestiers Non Ligneux en Afrique Centrale». FAO. Ayaba Hotel, Bamenda: May 3rd-5th 2010, FAO-CIFOR-SNV-World Agroforestry Center-COMIFAC.

[22] Mekongo, F. 2011. Amélioration de la chaîne de valeur des produits forestiers non ligneux (PFNL) exploités par les organisations féminines. Le cas des communes des Mbang et Lomié, Départements de la Kadey et du Haut Nyong, Région de l'Est, Cameroun. Yaounde, GIZ. Rapport de consultation.

[23] Nguiffo, S., Bigombe, L. P., Mondo, H. A., and Abilogo, E. 2002. The Ecofac Project and the Baka Pygmies of the Eastern Borders of the Dja Biosphere Reserve. East Province, Cameroon. Yaounde, Cameroon, Cantre for Environment and Development (CED).

[24] SNV 2013. How to facilitate successful collective sales of non-timber forest products. Manual for service providers. Yaounde, SNV-Cameroon.

[25] Mekongo, F., and Ngueko, R. 2008. Système D’information Sur Les Marches Des Produits Forestiers Non Ligneux Au Sud Cameroun. Yaounde, SNV,
FAO-CIFOR-SNV-World

Center-COMIFAC: 6.

Agroforestry

[26] Vermeulen, C., Julve, C., Doucet, J.-L. and Monticelli, D. 2009. “Community Hunting in Logging Concessions: Towards a Management Model for Cameroon's Dense Forests.” Biodiversity Conservation 18: 2705-2817.

[27] SNV, N. W. 2010. Pilot Phase Market Information System for NTFPs in North West Region. Project GCP/RAF/408/EC «Mobilisation et Renforcement des Capacités des Petites et Moyennes Entreprises impliquées dans les Filières des Produits Forestiers Non Ligneux en Afrique Centrale». Yaounde, FAO-CIFOR-SNV-World Agroforestry Center-COMIFAC.

[28] Cubbage, F., Harou, P., and Sills, E. 2007. "Policy Instruments to Enhance Multi-functional Forest Management.” Forest Policy and Economics 9 (7): 833-51.

[29] Higgins, K., and Prowse, S. 2010. Trade, growth and poverty: making Aid for Trade work for inclusive growth and poverty reduction. Working Paper 313. London, Overseas Development Institute: 37.

[30] Laven, A. C. 2010. The risks of inclusion: shifts in governance processes and upgrading opportunities for cocoa farmers in Ghana, KIT publishers. 